\title{
Evaluation of Pesticides on Dehydrogenase, Urease and Phosphatase Enzymes Activities in A Tropical Red Soil under Cabbage Cropping
}

\author{
Nyape Bam ${ }^{1,2^{*}}$, S. K. Patra ${ }^{1}$, Payel Pal ${ }^{1}$ and W. P. Devi ${ }^{2}$ \\ ${ }^{1}$ Department of Agricultural Chemistry and Soil Science, Bidhan Chandra Krishi \\ Viswavidyalaya, Mohanpur, Nadia, West Bengal, India \\ ${ }^{2}$ KVK East Kameng, Arunachal Pradesh, India \\ *Corresponding author
}

\begin{tabular}{|c|}
\hline Keywords \\
\hline $\begin{array}{l}\text { Pesticides, soil } \\
\text { dehydrogenase, } \\
\text { urease, phosphatase, } \\
\text { red soil, cabbage }\end{array}$ \\
\hline Article Info \\
\hline $\begin{array}{l}\text { Accepted: } \\
\text { 12 March } 2021 \\
\text { Available Online: } \\
10 \text { April } 2021\end{array}$ \\
\hline
\end{tabular}

A B S T R A C T
Occurrence of high density of pest infestation at different growth stages of cabbage results into severe yield reduction. Innumerable inorganic and organic pesticides are used to control pests; however it negatively affects soil enzymes. Five pest management schedules viz. FYM + RDF + pest management as per package of practice (PMPP), FYM + RDF + integrated pest management (IPM), FYM + RDF + organic pesticides, organic nutrients + organic pesticides (control) and FYM + RDF + pest management followed by farmers (PMF) were evaluated to assess the impacts of these pesticide residues on dehydrogenase, urease and phosphatase enzymes activity in soil under cabbage cropping. Results showed that inhibition of enzyme activity was mostly observed at high amounts of pesticides, but promotion or stimulation of enzyme activity was observed at low amounts. Highest inhibition of dehydrogenase activity (30.63\%) was observed in soil with higher concentration of pesticides with the treatment of FYM + RDF + PMF. Increased dehydrogenase enzyme activity (2.30\%) was noticed in soil treated with FYM + RDF + organic pesticides as compared to control. Dehydrogenase activity showed highest sensitivity to pesticides followed by urease and phosphatase whereas maximum stimulation was recorded with phosphatase. Treatment of FYM + RDF + IPM was found the best for augmenting soil enzymes activities, and thus advisable to the farmers for sustainable production of cabbage grown in tropical red soil.

\section{Introduction}

In modern explosive agriculture, various chemical fertilizers and pesticides have been used extensively for maximizing crop production to meet the food demand of the rising human population. Pesticides constitute both organic and inorganic agrochemicals of diversified chemical compositions. The judicious application of these chemicals is beneficial for sustaining the soil and crop productivity through controlling pest infestation in soil and plant system. However, the prolonged and indiscriminate use of the 
pesticides cause harmful effects on soil health, environmental pollution, food chain contamination and disrupt the microbial diversity and biological functions in soil (Ejah et al., 2004; Mahía et al., 2008; Muñoz- Leoz et al., 2013). Soil enzymes driven by microorganisms are the key indicators for several biochemical processes in soil (Caldwell, 2005; Riah et al., 2014). They play an important role in mineralization and transformation of organic matter and nutrient recycling in soil, energy transformation, stability in soil structure, nitrogen fixation, disease control, and other biochemical transformations such as ammonification, nitrification and phosphorus solubilization leading to increased vigour, growth and productivity of crop (Prasad Reddy et al., 1984; Husain et al., 2003; Karas et al., 2018; Jat et al., 2021).

Soil dehydrogenase is a potential intracellular enzyme in all living microbial cells. It is used for assessing the microbial oxidative activity in soil and a potential measure of microbial biomass and soil respiration (Subhani et al., 2001; Zhang et al., 2016). Dehydrogenase enzyme is considered to play a significant role in the biological oxidation of soil organic matter by donating hydrogen from organic substrates to inorganic acceptors (Zhang et al., 2010; Moeskops et al., 2009). It is originated from several sources like bacteria, fungi, protozoa and plant roots and can serve to transform the complex and even unavailable forms of organic $\mathrm{P}$ into inorganic available $\mathrm{P}$ forms through catalytic hydrolysis in the soil, which is subsequently absorbed by plants and microbes (Dick and Tabatabai, 1993; Hinsinger, 2001). Soil phosphatase activity is a potential detector of mineralization of organic phosphorus and biological activity of soils. It maintains and controls the rate of phosphorus cycling through soils, particularly in high phosphorus deficient organic soils (Chen et al., 1996). Acid phosphatase activity in general was found predominant in acid soils while alkaline phosphatase activity in neutral or alkaline soils (Dick et al., 2000). Addition of pesticides or inorganic $\mathrm{P}$ in soil can inhibit the enzymatic activities involved in the phosphorus cycle (Kalam et al., 2004). Soil urease is one of most active hydrolytic enzymes in soil and a key component in soil nitrogen cycle. It is derived mainly from plants and microorganisms and does exist both as intra- and extra-cellular enzyme (Riah et al., 2014). It catalyses the hydrolysis of applied urea into carbon dioxide and ammonia which is taken up by plants. Application of pesticides decreased activity of urease enzyme in soil due to reduced urea hydrolysis, which is beneficial, because it helps to maintain nitrogen availability to plants for longer period (Antonious, 2003). The urease activity in soil is either unaffected or inhibited by addition of pesticides depending upon the balanced soil fertilization and management practices.

Cabbage is one of the major vegetable crops in temperate and tropical climates of India. It is grown extensively during winter as well as summer season due to its wide adaptability. However, the crop is susceptible to several insect pest infestations in the field, which causes heavy economic losses to the farmers (Baidoo and Mochiah, 2016). Broad-spectrum of synthetic pesticides is applied to effectively control the pests. Among the vegetables in India, cabbage is the maximum pesticideconsuming crop. Moreover, pesticides have also entered into plant system causing more chance of pesticide intake to humans and animals. Many agricultural management strategies have been evolved to minimize the use of pesticides, soil health promotion and yield sustainability. There are innumerable evidences showed that different pesticides have inhibitory and/ or promotory effects on soil enzymes which is largely governed by chemical and recalcitrant nature of the pesticides, physical and chemical properties of 
soils and cropping conditions (Kiss et al., 1975). Keeping the above considerations in view, the present study was conducted to assess the impacts of different management schedules of pesticides on dehydrogenase, urease and phosphatase enzymes activity in a red soil of northern transition zone of Karnataka under cabbage cropping.

\section{Materials and Methods}

The field experiment was conducted during the summer season (March-June) of 2015-16 on cabbage in a red soil of northern transition zone of Karnataka belonging to the tropical climate of south India. The experimental site is located at $15^{\circ} 26^{\prime \prime} \mathrm{N}$ latitude and $75^{\circ} 07^{\prime \prime} \mathrm{E}$ longitude at an altitude of $678 \mathrm{~m}$ above mean sea level. The soil is sandy clay loam in texture.

Cabbage (Brassica oleracea var. capitata) cv. Golden head N50 was used as test crop. Five weeks old healthy seedlings were transplanted in the well prepared main field with crop geometry of $45 \mathrm{~cm}$ row to row and plant to plant distances. Farmyard manure @ $25 \mathrm{t} \mathrm{ha}^{-1}$ and recommended dose of fertilizer $\left(\mathrm{N}: \mathrm{P}: \mathrm{K}:: 150: 100: 125 \mathrm{~kg} \mathrm{ha}^{-1}\right.$ ) in the form of urea, single superphosphate and muriate of potash, respectively were applied as per adopted treatments. FYM including half dose of $\mathrm{N}$ and full dose of $\mathrm{P}$ and $\mathrm{K}$ were applied as basal during the final land preparation and remaining half dose of $\mathrm{N}$ was top-dressed at 45 days after transplanting. In organic nutrient schedule, only FYM was used as sources of nutrients. The crop was exposed to five types of pest management practices viz., $\mathrm{T}_{1}$ : FYM + $\mathrm{RDF}+$ pest management as per package of practice (PMPP), $\mathrm{T}_{2}: \mathrm{FYM}+\mathrm{RDF}+$ integrated pest management (IPM), $\mathrm{T}_{3}$ : FYM $+\mathrm{RDF}+$ organic source of pesticides, $\mathrm{T}_{4}$ : organic sources of nutrients + organic sources of pesticides (considered as control) and $\mathrm{T}_{5}$ : $\mathrm{FYM}+\mathrm{RDF}+$ pest management usually followed by farmers (PMF). The scheduling of different doses of plant protection chemicals against pest attack during the cropping period followed is given in Table 1 and Table 2 .

The routine intercultural operations like gap filling and manual weeding were followed uniformly in each sub-plot. The relevant physical and physicochemical characteristics of the initial experimental soil $(0-15 \mathrm{~cm})$ as determined by the standard methods (Piper, 1996; Jackson, 1973) are furnished in Table 3.

The treatment-wise and replication-wise composite soil samples $(0-15 \mathrm{~cm})$ were collected at harvest, processed, moistened to $60 \%$ of maximum water holding capacity (field capacity) by adding requisite amount of distilled water and pre-incubated at $37^{\circ} \mathrm{C}$ in a BOD incubator for a period of 1-day for urease and 7-day for phosphatase and dehydrogenase enzymes (Basavaraj, 1984). A known quantity of pre-incubated soil (5 $\mathrm{g}$ for dehydrogenase, $1 \mathrm{~g}$ for phosphatase and $10 \mathrm{~g}$ for urease activity) was placed in glass tubes and brought to field capacity. The tubes were covered with rubber stoppers and were incubated in a BOD (Biological Oxygen Demand) incubator at a temperature of $37^{\circ} \mathrm{C}$ in order to restore the normal biological activity. Phosphatase activity was determined by quantifying P-nitrophenol hydrolyzed from P-nitro phenol phosphate used as a substrate (Tabatabi, 1982). Urease activity was determined by quantifying unhydrolysed urea from which amount of urea hydrolyzed was computed (Watts and Chrisp, 1954). Dehydrogenase activity was estimated by quantifying triphenyl formazan (TPF) formed from 2,3,5-triphenyl tetrazolium chloride (TTC) (Casida et al., 1964). The per cent inhibition or promotion of enzymes activity due to various chemicals applied in cabbage field is calculated as, $(\mathrm{s}-\mathrm{t}) \times 100 / \mathrm{s}$ where, $\mathrm{s}=$ the enzyme activity value for control and $\mathrm{t}=$ the enzyme activity value for treatments. 
The data obtained for different treatments were subjected to analysis of variance (ANOVA) using Microsoft Excel 2016 and SPSS version 23.0 (SPSS, Inc.). Fisher's least significant difference (LSD) test was employed and treatments means were separated by Duncan Multiple Range Test (DMRT) at $P<0.05$ level (Gomez and Gomez, 1984).

\section{Results and Discussion}

\section{Effect of pesticides on soil dehydrogenase activity}

The changes in dehydrogenase activity were significantly affected by the application of pestiticides (Table 4). Highest significant reduction of dehydrogenase activity in comparison with control $\left(\mathrm{T}_{4}\right)$ was observed in $\mathrm{T}_{5}\left(5.73 \mu \mathrm{g} \mathrm{TPF} \mathrm{g}^{-1}\right.$ soil $\left.\mathrm{hr}^{-1}\right)$ where fertilizers and manures as per recommendation and pesticides as per farmers' practice were applied. This reduction was followed by $\mathrm{T}_{2}$ $\left(7.95 \mu \mathrm{g}\right.$ TPF $\mathrm{g}^{-1}$ soil $\mathrm{hr}^{-1}$ ) where RDF and FYM were incorporated as per package of practices and pest control through integrated pest management and $\mathrm{T}_{1}\left(7.85 \mu \mathrm{g}\right.$ TPF g ${ }^{-1}$ soil $\mathrm{hr}^{-1}$ ) where nutrients and pesticides were applied as per package of practices. The latter two treatments $\left(T_{1}\right.$ and $\left.T_{2}\right)$ were statistically at par. Significantly highest dehydrogenase activity as compared to control was found with $\mathrm{T}_{3}\left(8.45 \mu \mathrm{g}\right.$ TPF g ${ }^{-1}$ soil hr$\left.{ }^{-1}\right)$ where RDF and FYM were administered along with organic pesticides. The control treatment $\mathrm{T}_{4}$ constituting only organic sources of nutrients as well as pesticides showed the dehydrogenase activity of $8.26 \mu \mathrm{g} \mathrm{TPF} \mathrm{g}{ }^{-1}$ soil $\mathrm{hr}^{-1}$.

The soil exposure of pesticides application may affect enzymes activities either directly or indirectly. Direct inhibition of intracellular and extracellular enzymes can occur by binding of pesticides to protein molecules in a reversible mode (Browman and Tabatabi, 1978). Indirect inhibition refers to changes in microbial activities and concurrent altered intra- and extracellular enzyme levels (Cervelli et al., 1978). Soil dehydrogenase activity is often used as a measure of the metabolic activity of microorganisms in the soil. Any exogenous toxicant addition to soil may modify the microorganisms and thus dehydrogenase enzymes. Several variations in dehydrogenase activity have been observed in soils with different kinds of pesticides and nutrients. The per cent inhibitory/promotory values for various organic and inorganic treatments on dehydrogenase activity calculated with reference to control are summarized in Table 7.

It is conspicuous from the computed results that the promotion or demotion of dehydrogenase activity in soil was mainly controlled by the kinds of pesticides used for pest management programme. Soils treated with inorganic pesticides showed mostly inhibitory effect on soil dehydrogenase enzyme activity while stimulatory effects in soils treated with organic pesticides when compared with the control providing only organic sources of nutrients and pesticides. The decrease in enzyme activity with increase in concentration and spray schedule was due to the lethal action of applied pesticides on microorganisms, which in turn affected the enzymatic processes. These findings have been supported by Chandrayan and Sethunathan (1980) with $\mathrm{HCH}$ and carbaryl; $\mathrm{Tu}$ (1981) with trebufos, triazophos and trichlornar and Kalam et al., (2004) with profenofos with suppressed dehydrogenase activity.

Highest inhibition of dehydrogenase activity (30.63\%) was observed with higher concentration of pesticides in $\mathrm{T}_{5}$ comprising of $\mathrm{FYM}+\mathrm{RDF}+$ pest management followed by farmers. This might be attributed to physical 
structure of the chemicals applied which likely have more lethal action to microorganisms releasing dehydrogenase enzymes. Relatively less inhibition of dehydrogenase activity was demonstrated in $\mathrm{T}_{1}(4.96 \%)$ and $\mathrm{T}_{2}(3.75 \%)$. Inhibition or demotion of dehydrogenase activity in soil was noticed by Purushothaman et al., (1974) for cytrolane, Srimathi et al., (1986) for bromophos and Nelson and $\mathrm{Li}$ (1985) for captan. Mayanglambam et al., (2005) recorded $35.5 \%$ inhibition of dehydrogenase activity by application of quinalphos which almost similar to our findings. Topal et al., (2014) revealed that acute exposure to chlorpyrifos showed time dependent decrease in glucose-6-phosphate dehydrogenase enzyme activity at all concentrations. Sanchez-Hernandez et al., (2017) also recorded $47 \%$ reduction of dehydrogenase activity as compared to control.

Increased dehydrogenase enzyme activity (2.3\%) over control was only observed in soil treated with FYM + RDF + organic sources of pesticides $\left(T_{3}\right)$ which could be attributed to increased availability of soil nutrients used by microorganisms releasing dehydrogenase enzymes. This observation is in line with Manna and Ganguly (2001) that incorporation of FYM and N-fertilizer increased the soil microbial biomass C, N and P. Similarly, Sun et al., (2003) reported long-term application of mineral NPK fertilizer combined with organic manure significantly increased the contents of organic matter, total $\mathrm{N}, \mathrm{P}$ and available $\mathrm{N}$ in soil which resulted in increased soil enzyme activities including dehydrogenase.

\section{Effect of pesticides on soil phosphatase activity}

The analytical data on significant impacts of different pesticides on soil phosphatase activity is furnished in Table 5. Maximum inhibition of soil phosphatase activity relative to control treatment $\left(\mathrm{T}_{4}\right)$ was observed in $\mathrm{T}_{5}$ (5.40 $\mu \mathrm{g}$ P-NP $\mathrm{g}^{-1}$ soil $\mathrm{hr}^{-1}$ ) which was followed by $\mathrm{T}_{1}\left(5.83 \mu \mathrm{g}\right.$ P-NP $\mathrm{g}^{-1}$ soil $\left.\mathrm{hr}^{-1}\right)$, while maximum and marginal promotion of phosphatase activity was found in $\mathrm{T}_{2}(6.30 \mu \mathrm{g}$ P-NP g ${ }^{-1}$ soil $\left.\mathrm{hr}^{-1}\right)$ and $\mathrm{T}_{3}\left(6.07 \mu \mathrm{g}\right.$ P-NP g ${ }^{-1}$ soil $\mathrm{hr}^{-1}$ ), respectively.

The treatments $T_{4}$ and $T_{3}$ were statistically at par with each other. The various scheduling of organic and inorganic pesticide in conjunction with FYM + RDF either demoted or promoted the phosphatase activity, but mostly exhibited inhibitory effect at higher concentrations with more number of spraying. These observations were supported by Zhang et al., (2013) who recorded the significant antagonism effects on soil phosphatase at higher concentrations of acetochlor with As (III).

With reference to control, higher inhibitory effect of pesticides on phosphatase activity $(10.30 \%)$ was found with $\mathrm{T}_{5}$ accommodating higher nutritional dose and more number of pesticides applications adopted by farmer followed by that of $\mathrm{T}_{1}(3.16 \%)$ showing less inhibition effect (Table 7).

This could be ascribed to the toxic actions of insecticides on P-solubilizing population which might have altered the membrane permeability of the microorganisms producing phosphatase enzymes.

In contrast, Voets et al., (1974) recorded $61.8 \%$ inhibition of the phosphatase activity in forest soil as a result of atrazine application. Similar but rather increasing trends were noticed by Tabatabai and Bremner (1969) for p-nitrophenyl phosphate, Krishnamurthy (1989) for fenvelerate, Madhuri and Rangaswamy (2002) for dichlorvos, phorate and methomyl, Kalam et al., (2004) for propiconazole, Kennedy and Arathan (2004) for carbofuran and Sanchez-Hernandez et al., (2017) for chlorpyrifos. 
Table.1 Pesticide application pattern

\begin{tabular}{|c|c|c|c|c|c|c|}
\hline Treatment & $\begin{array}{c}\text { 15 DAS at } \\
\text { Nursery }\end{array}$ & 15 DAT & 30 DAT & 45 DAT & 60 DAT & 75 DAT \\
\hline $\mathbf{T}_{\mathbf{1}}$ & Dimethoate & Dimethoate & Dimethoate & Malathion & Malathion & Malathion \\
\hline $\mathbf{T}_{\mathbf{2}}$ & Dimethoate & Neem oil & Neem oil & Neem oil & Dimethoate & Neem oil \\
\hline $\mathbf{T}_{\mathbf{3}}$ & Dimethoate & Neem oil & Neem oil & Neem oil & Neem oil & Neem oil \\
\hline $\mathbf{T}_{\mathbf{4}}$ & Dimethoate & Neem oil & Neem oil & Neem oil & Neem oil & Neem oil \\
\hline $\mathbf{T}_{\mathbf{5}}$ & Dimethoate & Endosulfan & Dimethoate & Dimethoate & Indoxacarb & Indoxacarb \\
\hline
\end{tabular}

Table.2 Dosages of pesticide application

\begin{tabular}{|c|c|}
\hline Chemical used & Dosage \\
\hline Endosulfan 35 EC & $2 \mathrm{ml} \mathrm{L}^{-1}$ \\
\hline Dimethoate & $2 \mathrm{ml} \mathrm{L}^{-1}$ \\
\hline Neem oil & $2 \mathrm{ml} \mathrm{L}^{-1}$ \\
\hline Indoxacarb 14.5 SC & $5 \mathrm{ml} \mathrm{L} \mathrm{L} \mathrm{L}^{-1}$ \\
\hline Malathion & $2 \mathrm{~g} \mathrm{~L}^{-1}$ \\
\hline
\end{tabular}

Table.3 Physicochemical characteristics of the experimental soil

\begin{tabular}{|c|c|}
\hline Soil properties & Value \\
\hline Clay (\%) & 35.2 \\
\hline Silt (\%) & 7.6 \\
\hline Fine sand (\%) & 29.2 \\
\hline Coarse Sand (\%) & 28.0 \\
\hline Texture & Sandy clay loam \\
\hline Water holding capacity (\%) & 59.1 \\
\hline Organic carbon $\left(\mathbf{g ~ k g}^{-\mathbf{1}}\right)$ & 2.4 \\
\hline $\mathbf{p H}$ & 7.4 \\
\hline EC $\left(\mathbf{~ d S ~ ~ ^ { - 1 } )}\right.$ & 0.23 \\
\hline CEC $\left[\mathbf{c m o l}(+) \mathbf{~ k g}^{-\mathbf{1}}\right]$ & 33.0 \\
\hline
\end{tabular}

Soil $\mathrm{pH}$ and EC determined in 1:2.5 soil: water suspension

Table.4 Effect of pesticides on soil dehydrogenase activity

\begin{tabular}{|c|c|}
\hline Treatments & Dehydrogenase activity ( $\mu \mathrm{g}$ TPF $\mathrm{g}^{-1}$ soil $\mathrm{hr}^{-1}$ ) \\
\hline $\mathrm{T}_{1}: \mathrm{FYM}+\mathrm{RDF}+\mathrm{PMPP}$ & $7.85(2.97)^{\mathrm{c}}$ \\
\hline$T_{2}: F Y M+R D F+I P M$ & $7.95(2.99)^{\mathrm{c}}$ \\
\hline$T_{3}:$ FYM + RDF + Organic pesticides & $8.45(3.07)^{\mathrm{a}}$ \\
\hline $\mathbf{T}_{4}$ : Organic nutrients + Organic pesticides & $8.26(3.04)^{b}$ \\
\hline $\mathrm{T}_{5}: \mathrm{FYM}+\mathrm{RDF}+\mathrm{PMF}$ & $5.73(2.59)^{d}$ \\
\hline S.Em. \pm & 0.06 \\
\hline CD (0.05) & 0.17 \\
\hline
\end{tabular}

The values in the parenthesis are transformed into $\sqrt{\mathrm{X}+1}$; means followed by the same letters in a column are not differed significantly by Dunkan Multiple Range Test $(P<0.05)$; PMPP: pest management as per package of practice, IPM: integrated pest management, PMF: pest management followed by farmers 
Table.5 Effect of pesticides on soil phosphatase activity

\begin{tabular}{|c|c|}
\hline Treatments & Phosphatase activity ( $\mu \mathrm{g}^{\mathrm{P}-\mathrm{NP}^{-1}}$ soil $\mathrm{hr}^{-1}$ ) \\
\hline 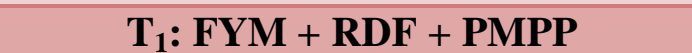 & $5.83(2.61)^{\mathrm{b}}$ \\
\hline $\mathrm{T}_{2}: \mathrm{FYM}+\mathrm{RDF}+\mathrm{IPM}$ & $6.30(2.70)^{\mathrm{a}}$ \\
\hline$T_{3}: F Y M+$ RDF + Organic pesticides & $6.07(2.66)^{\mathrm{ab}}$ \\
\hline $\begin{array}{c}\mathbf{T}_{4} \text { : Organic nutrients + Organic } \\
\text { pesticides }\end{array}$ & $6.02(2.65)^{\mathrm{ab}}$ \\
\hline$T_{5}: F Y M+R D F+P M F$ & $5.40(2.53)^{\mathrm{e}}$ \\
\hline S.Em. \pm & 0.019 \\
\hline CD (0.05) & 0.057 \\
\hline
\end{tabular}

The values in the parenthesis are transformed into $\sqrt{\mathrm{X}+1}$; means followed by the same letters in a column are not differed significantly by Dunkan Multiple Range Test $(P<0.05)$; PMPP: pest management as per package of practice, IPM: integrated pest management, PMF: pest management followed by farmers

Table.6 Effect of pesticides on soil urease activity

\begin{tabular}{|c|c|}
\hline Treatments & Urease activity ( $\mu \mathrm{g}$ urea $\mathrm{g}^{-1}$ soil $\mathrm{hr}^{-1}$ ) \\
\hline 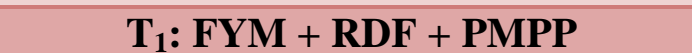 & $259.25(16.13)^{\mathrm{a}}$ \\
\hline$T_{2}: F Y M+R D F+I P M$ & $270.50(16.48)^{\mathrm{a}}$ \\
\hline$T_{3}: F Y M+$ RDF + Organic pesticides & $268.50(16.41)^{\mathrm{a}}$ \\
\hline $\begin{array}{c}\mathrm{T}_{4} \text { : Organic nutrients + Organic } \\
\text { pesticides }\end{array}$ & $260.25(16.16)^{\mathrm{a}}$ \\
\hline$T_{5}:$ FYM + RDF + PMF & $183.13(13.57)^{b}$ \\
\hline S.Em. \pm & 0.15 \\
\hline CD (0.05) & 0.45 \\
\hline
\end{tabular}

The values in the parenthesis are transformed into $\sqrt{\mathrm{X}+1}$; means followed by the same letters in a column are not differed significantly by Dunkan Multiple Range Test $(P<0.05)$; PMPP: pest management as per package of practice, IPM: integrated pest management, PMF: pest management followed by farmers

Table.7 Percentage inhibition or promotion of enzyme activity in soil

\begin{tabular}{|c|c|c|c|}
\hline \multirow[t]{2}{*}{ Treatments } & \multicolumn{3}{|c|}{ Percentage inhibition or promotion } \\
\hline & $\begin{array}{l}\text { Dehydrogenase } \\
\text { activity }\end{array}$ & $\begin{array}{l}\text { Phosphatase } \\
\text { activity }\end{array}$ & $\begin{array}{r}\text { Urease } \\
\text { activity }\end{array}$ \\
\hline $\mathrm{T}_{1}: \mathrm{FYM}+\mathrm{RDF}+\mathrm{PMPP}$ & 4.96 & 3.16 & 0.38 \\
\hline$T_{2}: F Y M+R D F+I P M$ & 3.75 & $4.65^{*}$ & $3.94 *$ \\
\hline$T_{3}:$ FYM + RDF + Organic pesticides & $2.30^{*}$ & $0.83^{*}$ & $3.17 *$ \\
\hline $\begin{array}{c}\mathrm{T}_{4} \text { : Organic nutrients }+ \text { Organic } \\
\text { pesticides }\end{array}$ & 0.00 & 0.00 & 0.00 \\
\hline 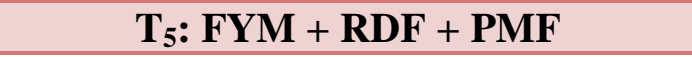 & 30.63 & 10.30 & 29.63 \\
\hline
\end{tabular}

*indicate promotion; PMPP: pest management as per package of practice, IPM: integrated pest management, PMF: pest management followed by farmers 
Treatment receiving FYM + RDF + IPM $\left(\mathrm{T}_{2}\right)$ employing minimum use of chemical pesticides showed maximum stimulatory or promotory effect on phosphatase activity (4.65\%) as compared to control (Table 7). This increase in soil phosphatase activity might be due to increase in P-solubilizers as a consequence of degradation of applied insecticides or products which might have served as a carbon source. Dimethoate, the only chemical pesticide applied in this treatment, is an organophosphorus group of insecticides which might have provided direct source of $\mathrm{P}$ after its degradation. This stimulatory effect of pesticides on $\mathrm{P}$ solubilizers was supported by Sivasithamparam (1969) with chlorpyrifos and Congregado et al., (1979) with organophosphorus insecticides.

Likewise, treatment having FYM + RDF + organic source of pesticides $\left(\mathrm{T}_{3}\right)$ also showed minor stimulatory effect on soil phosphatase activity which could be attributed to applied fertilizers and manure serving as sources of nutrients to soil microorganisms releasing phosphatase enzymes in soil. This is in agreement with the works of Gopal Reddy (1997) who reported highest dehydrogenase, urease and phosphatase activity with RDN + FYM as compared to treatment with only inorganic source of RDF. Lalfakzuala et al., (2006) reported that fertilizer treatment increases microbial population number and microbial enzymatic activity. Kondratowicz (2007) also found that fertilization with nitrogen and manure resulted in an increase in microbial population and higher enzymatic activity in soil.

\section{Effect of pesticides on soil urease activity}

The impacts of various treatments of pesticides on soil urease activity were at par except in treatment $T_{5}$ where fertilizers and manure as per recommendation and pesticides as per farmers' practice adopted, which showed the highest reduction of urease activity $\left(183.13 \mu \mathrm{g}\right.$ urea $\mathrm{g}^{-1}$ soil $\left.\mathrm{hr}^{-1}\right)$ in comparison with control (Table 6).

Highest inhibition on soil urease activity was observed in $\mathrm{T}_{5}(29.63 \%)$ with higher nutritional dose and more number of pesticides application followed by farmers. The inhibitory effect of pesticides on urease may be direct or indirect. An indirect effect may result from desorption of the enzyme. The stability of urease increases by sorption on soil; after desorption its activity will be reduced as reported by Lampe and Aldag (1979). The inhibition of urease activity with higher pesticides applications may be attributed to the higher sand content, which may result in lesser sorption of the chemical and also desorption of the urease from the soil colloids. Inhibitory effect on urease activity upon insecticide application was also observed by Lethbridge and Burns (1976) with organophosphorus, Basavaraj (1984) with combined application of 2,4-D, carbofuran and quintozene, Srimathi et al., (1986) with bromophos, Elliot (1989) with fungicides, Kennedy et al., (1999) with carbofuran and Laksmikantha (2000) with fenvalerate, quinalphos and endosulfan.

Treatments $T_{1}, T_{2}$ and $T_{3}$ showed relatively higher urease activity than control which might be attributed to the increased microbial population due to addition of fertilizers and FYM as enzyme activity is directly related to the microbial count in soil as reported by Dinesh et al., (2000). The increased urease activity with addition of RDF and FYM was also reported by Sriramachandrasekharan (2002).

The most substantial index of biological activity in soil is its enzymatic activity which can give an idea of the biochemical processes in soil. The enzyme acts as indicator of the 
soil quality and fertility. Among three soil enzymes studied, dehydrogenase showed highest sensitivity followed by urease. Lowest reduction in enzymatic activity was observed in case of soil phosphatase which is supported by work of Kawalczyk and Wlike (1989) who observed no significant effect on phosphatase activity by sodium dodecyl benzosulphonate, a formulation agent for various pesticides. Monarik and Malickenko (1969) did not observe much effect of triazines on phosphatase activity in soil. Lewis et al., (1978) also reported the same. Oleszczuk et al., (2014) observed that biochar stimulated the activity of enzymes and it also reduced the negative effect of pesticides on the enzymatic activity and on certain microorganisms in the Microbial Assay for Risk Assessment (MARA). Majumder and Das (2016) reported that insecticides incorporation in soil significantly increased the acid and alkaline phosphatase activities of the soil.

The result of the study showed that soil enzymes activities were inhibited maximum with higher concentrations of inorganic pesticides with the treatment of FYM + RDF + pest management followed by farmers and promoted with the treatment of FYM + RDF + organic source of pesticides. Higher concentrations of chemical pesticides with more number of spraying mostly showed inhibitory effect on soil enzymes, but treatment with FYM + RDF + integrated pest management (IPM) with minimum use of chemical pesticides or pest management with organic pesticides showed stimulatory effect on enzymes activities. Among three soil enzymes studied, dehydrogenase showed highest sensitivity to pesticides applied followed by urease and phosphatase. Considering the efficacy of pesticides on enzyme activity, application of FYM + RDF + IPM recorded was found the best treatment approach. The information generated help to understand the effect of applied pesticides on soil enzymes which are of paramount importance in assessing nutrient recycling and transformation in soil system for sustaining crop productivity.

\section{References}

Antonious, G. F. 2003. Impact of soil management and two botanical insecticides on urease and invertase activity. Journal of Environmental Science and Health (Part B), 38: 479488.

Baidoo, P. and Mochiah, M. 2016. Comparing the effectiveness of garlic (Allium sativum L.) and hot pepper (Capsicum frutescens L.) in the management of the major pests of cabbage (Brassica oleracea L.). Sustainable Agriculture Research, 5: 83-91.

Basavaraj, B. 1984. Effect of pesticides on the activity of urease, phosphatase and dehydrogenase in black and red soils of Karnataka. M. Sc (Agri.) Thesis, Univ. Agric. Sci., Bangalore.

Browman, M. G. and Tabatabi, M. A. 1978. Phosphatase activity of soil. Soil Science. Society of America Journal, 42: 284-290.

Caldwell, B. A. 2005. Enzyme activities as a component of soil biodiversity: A review. Pedobiologia (Jena), 49: 637644. doi:10.1016/j.pedobi.2005.06.003.

Casida, L. E., Klein, D. A. and Santon, J. 1964, Soil dehydrogenase activity. Soil Science, 98: 371-376.

Cervelli, S., Nannipieri, P. and Sequi, P. 1978, Interaction between agrochemicals and soil enzymes. In: Soil Enzymes (R.G. Burns (Ed.), Academic press, New York, USA, pp 251-293.

Chandrayan, K. and Sethunathan, N. 1980. Effect of $\mathrm{HCH}$, carbaryl, benomyl and atrazine on dehydrogenase activity in flooded soil. Bulletin of Environmental 
Contamination and Toxicology, 24: 379-382.

Chen, H., Li, Y. Q., Chen, D. D., Zhang, Y., Wu, L. M. and Ji, J. S. 1996. Soil phosphorus fractions and their availability in Chinese fir plantations in south China. Forestry Research, 9: 121-126.

Congregado, S., Docores, S. P. and Juarea, P. 1979. Effects of two organophosphorus insecticides on the P-solubilising bacteria. Applied and Environmental Microbiology, 37: 169171.

Dick, W. A. and Tabatabai, M. A. 1993. Significance and potential uses of soil enzymes. In: Soil microbiology ecology: Application in agricultural and environment management. Ed F. B. Metting. Marcel Dekker, New York, pp. 95-125.

Dick, W. A., Cheng, L. and Wang, P. 2000. Soil acid and alkaline phosphatase activity as $\mathrm{pH}$ adjustment indicators. Soil Biology and Biochemistry, 32: 1915-1919.

Dinesh, R., Dubey, R. P., Ganeshamurthy, A. N. and Prasad, G. S. 2000. Organic manuring in rice-based cropping system: effects on soil microbial biomass and selected enzyme activities. Current Science, 79 (12): 1716-1720.

Ejaz, S., Akram, W., Lim, C. W., Lee, J. J. and Hussain, I. 2004. Endocrine disrupting pesticides: a leading cause of cancer among rural people. Experiment Oncology, 26: 98-105.

Elliot, G. C. 1989. Effects of inhibitors of microbial activity on urea hydrolysis and nitrification in a soilless potting medium. Acta Horticulture, 238: 173180.

Gomez, K. A., and A. A. Gomez. 1984. Statistical Procedures for Agricultural
Research. 2nd Ed., John Wiley and Sons, New York, USA.

Gopal Reddy, B. 1997. Soil health under integrated nutrient management in maize soyabean cropping system. Ph.D. Thesis, ANGRAU, Hyderabad. India.

Hinsinger, P. 2001. Bioavailability of soil inorganic $\mathrm{P}$ in the rhizosphere as affected by root-induced chemical changes: a review. Plant and Soil, 237: 173-195.

doi: 10.1023/A:1013351617532.

Husain, S., Siddique, T., Salem, M., Arshad, M. and Khalid, A. 2003. Impact of pesticides on soil microbial diversity, Enzym and biochemical reactions, Advances in Agronomy, 102: 159-200.

Jackson, M. L. 1973. Soil Chemical Analysis. Prentice Hall of India Pvt. Ltd., New Delhi.

Jat, H. S., Datta, A., Choudhary, M., Sharma, P. C., Dixit, B. and Jat, M. L. 2021. Soil enzymes activity: Effect of climate smart agriculture on rhizosphere and bulk soil under cereal based systems of north-west India. European Journal of Soil Biology, 103: 103292. doi.org/10.1016/j.ejsobi.2021.103292.

Kalam, A., Tah, J. and Mukherjee, A. K. 2004. Pesticide effects on microbial population and soil enzyme activities during vermicomposting of agricultural waste. Journal of Environmental Biology, 25 (2): 201208.

Karas, P. A., Baguelin, C., Pertile, G., Papadopoulou, E. S., Nikolaki, S., Storck, V., Ferrari, F., Trevisan, M., Ferrarini, A., Fornasier, F., Vasileiadis, S., Tsiamis, G., G. Martin-Laurent, G. and Karpouzas, D. G. 2018. Assessment of the impact of three pesticides on microbial dynamics and functions in a lab-to-field experimental 
approach. Science of the Total Environment, pp 636-646.

Kawalczyk, T. and Wilke, B. M. 1989. Effects of LAS and phosdrin on the biological activity in soil. Mitteilingender Deutchen Bodenkundlichen Gesellschaft, 59 (1): 593-598.

Kennedy, Z. J. and Arathan, S. S. 2004. Influence of carbofuran on the activity of soil enzymes in submerged rice soil ecosystem. Biotechnology Microbes Sustainable Utilization, pp 322-326.

Kennedy, Z. J., Kumar, K. and Deiveekasundaram, H. 1999. Influence of graded levels of carbofuran on soil microbial population, nitrification process and its persistence in the soil. Journal of Ecology and Environment, 9: 251-256.

Kiss, S., Dragon-Bularda, M. and Radubesm, R. 1975. Biological significance of enzymes accumulated in soils. Advances in Agronomy, 27: 25-87.

Kondratowicz, M. K. 2007. Susceptibility of organic matter to oxidation and soil microbiological activity under conditions of varied crop rotation systems and fertilization. Polish Journal of Soil Science, 40 (1): 89-99.

Krishnamurthy, K. O. 1989. Effect of pesticides on phosphate solubilizer microorganisms. M.Sc. (Agri.) Thesis, University of Agricultural Sciences, Dharwad.

Laksmikantha H. C. 2000. Effect of foliar insecticides on soil microorganisms and their biochemical processes in soils of Gulbarga. M.Sc. (Agri.) Thesis, University of Agricultural Sciences, Dharwad.

Lalfakzuala, R., Kayang, H. and Dkhar, M. S. 2006. Effect of fertilizers treatment on soil microbial population numbers and enzyme activities under leguminous cultivation. Journal of Hill Research, 19 (1): 13-23.
Lampe, D. and Aldag, R. 1979. Urease activity of different soils and the effect of herbicides on it. Miffeilunges Der Dentschen Bodenkundlichen Gessellschaft, 29 (1): 433-441.

Lethbridge, G. and Burns, R. G. 1976. Inhibition of soil urease by organophosphorus insecticides. Soil Biology and Biochemistry, 8: 99-102.

Lewis, J. A., Papvixas, G. L. and Hora, T. S. 1978. Effect of some herbicides on microbial activity in soil. Soil Biology and Biochemistry, 10: 137-141.

Madhuri, R. J. and Rangaswamy, V. 2002. Influence of selected insecticides on Phosphatase activity in groundnut (Arachis hypogeae L.) soils. Journal of Environmental Biology, 23 (4): 393397.

Mahia, J., Cabaneiro, A., Carballas, T. and Diaz-Ravina, M. 2008. Microbial biomass and $\mathrm{C}$ mineralization in agricultural soils as affected by atrazine addition. Biology and Fertility of Soils, 45 (1): 99-105. 10.1007/s00374-008-0318-y.

Majumder, S. P. and Das, A. C. 2016. Phosphate-solubility and phosphatase activity in Gangetic alluvial soil as influenced by organophosphate insecticide residues, Ecotoxicology and Environmental Safety, 126: 56-61.

Manna, M. C. and Ganguly, T. K. 2001. Influence of FYM and ferilizer $\mathrm{N}$ on soll microbial biomass dynamics, turnover and activity of enzymes in a Typic haplustert under soybean-wheatfallow system. Indian Journal of Agricultural Research. 35 (1): 48-51.

Mayanglambam, T., Vig, K. and Singh, D. K. 2005. Quinalphos persistence and leaching under field conditions and effects of residues on dehydrogenase and alkaline phosphomonoesterases activities in soil. Bulletin Environmental Contamination 
Toxicology, 75 (6): 1067-1076.

Moeskops, B., Sukristiyonubowo, Husen, E., Herawaty, L., Carvalho Franca, S. De., Buchan, D. and Neve, S. De. 2009. Soil microbial properties under intensive organic and conventional vegetable production in West Java. Communications in Agricultural and Applied Biological Sciences, 74 (4): 89-94.

Monarik, A. V. and Malickenko, K. 1969. The effect of symmetrical triazines on Phosphatase and Urease activity in the soil. Fiz. Biokhin. Kult. Rust., 1: 173178.

Muñoz- Leoz, B., Garbisu, C., Charcosset, J., Sanchez-Perez, J. M., Antigudad, I. and Ruiz romera, E. 2013. Non-target effects of three formulated pesticides on microbially-mediated processes in a clay-loam soil. Science of the Total Environment, 449:345-354.

Nelson, E. E. and Li, C. Y. 1985. Persistence of benomyl and captan and their effects on microbial activity in field soils. Bulletin of Environmental Contamination and Toxicology, 34 (4): 533-540.

Oleszczuk, P., Josko, I., Futa, B., PasiecznaPatkowska, S., Pałys, E. and Kraska, P. 2014. Effect of pesticides on microorganisms, enzymatic activity and plant in biochar amended soil. Geoderma, 214-215: 10-18. doi.org/10.1016/j.geoderma.2013.10.0 10.

Piper, C. S. 1966. Soil and Plant Analysis. Hans Publisher, Bombay.

Prasad Reddy, B., Dhanaraj, P. and Narayana Rao, V. 1984. Effects of insecticides on soil microorganisms. In: Insecticide Microbiology (R. Lal ed.), (C) SpringerVerlag Berlin Heidelberg.

Purushothaman, D., Marimuthu, T. and Keravan, R. 1974. Respiration and Dehydrogenase activity of soil as influenced by application of cytrolane. Indian Journal of Experimental Biology, 12: 580-581.

Riah, W., Laval, K., Laroche-Ajzenberg, E., Mougin, C., Latour, X. and Trinsoutrot-Gattin, I. 2014. Effects of pesticides on soil enzymes: a review. Environmental Chemistry Letters, 12: 257-273. doi 10.1007/s10311-0140458-2.

Sanchez-Hernandez, J. C., Sandoval, M. and Pierart, A. 2017. Short-term response of soil enzyme activities in a chlorpyrifos-treated mesocosm: Use of enzyme-based indexes. Ecological Indicators, 73: 525-535. doi.org/10.1016/j.ecolind.2016.10.022.

Sivasithamparam, K. 1969. Some effects of an insecticide (dursban) and a weed killer (linuron) on the microflora of a submerged soil. RISO, 19: 339.

Srimathi, M. S., Karnath, N. G. K. and Majumdar, S. K. 1986. Influence of bromophos on some biological activities of soil. Journal of Soil Biology and Ecology, 6: 9-15.

Sriramachandrasekharan, M. V. 2002. Effect of fertilizers on dehydrogenase and urease activity in soil under crop rotation. Advances in Plant Science, 15 (1): 207-212.

Subhani, A., Changyong, H., Zhengmiao, X., Min, L. and El-ghamry, A. M. 2001. Impact of soil environment and agronomic practices on microbial/dehydrogenase enzyme activity in soil - a review. Pakistan Journal of Biological Sciences, 4 (3): 333-338.

Sun, R., Zhao, B. Q., Zhu, L. S., Xu, J. And Zhang, F. D. 2003. Effect of long-term fixed-site fertilization on soil enzyme activities and its role in adjustingcontrolling soil fertility. Plant Nutrition and Fertilizer Science, 9 (4): 406-410. 
Tabatabai, M. A. 1982. Soil Enzymes. In: Methods of Soil Analysis, Part 2 (A. L. Page, R. H. Miller and D. R. Keeny Eds.), American Society of Agronomy, Soil Science Society of America, Madison, Wisconsin, USA, pp 903947.

Tabatabai, M. A. and Bremner, J. M. 1969. Use of p-nitrophenyl phosphate for assay of soil Phosphatase activity. Soil Biology and Biochemistry, 1: 301-307.

Topal, A., Atamanalp, M., Oruc, E., Kurıci, M., Kocaman, E. M. 2014. Apoptotic effects and glucose-6-phosphate dehydrogenase responses in liver and gill tissues of rainbow trout treated with chlorpyrifos. Tissue and Cell, 46: 490-496.

doi.org/10.1016/j.tice.2014.09.001.

Tu, C.M. 1981. Effects of pesticides on activities of enzymes and microorganisms in a clay soil. Journal of Environmental Science and Health, 16: 179-181.

Voets, J. P., Meerschman, P. and Verestrate, W. 1974. Soil microbiological and biochemical effects of longterm atrazine application. Soil Biochemistry,
8: $149-152$.

Watts, G. W. and Chrisp, J. D. 1954. Spectrophotometric method for determination of urea. Analytical Chemistry, 26: 452-453.

Zhang, C., Liu, G., Xue, S. and Wang, G. 2016. Soil bacterial community dynamics reflect changes in plant community and soil properties during the secondary succession of abandoned farmland in the Loess Plateau. Soil Biology and Biochemistry, 97: 40-49.

Zhang, N., Xing-Dong, H. E., Yu-Bao, G., Yong-Hong, Li, Hai-Tao, W., Di, Ma, Zhang, D. R. and Yang, S. 2010. Pedogenic carbonate and soil dehydrogenase activity in response to soil organic matter in Artemisia ordosica community. Pedosphere 20 (2): 229-235. doi.org/10.1016/s10020160(10)60010-0.

Zhang, Y., Zhang, F., Zhang, G. C., and Guan, L. Z. 2013. Single and combined effects of As (III) and Acetochlor on phosphatase activity in Soil. Journal of Integrative Agriculture, 12 (6): 10791086.

\section{How to cite this article:}

Nyape Bam, S. K. Patra, Payel Pal and Devi, W. P. 2021. Evaluation of Pesticides on Dehydrogenase, Urease and Phosphatase Enzymes Activities in A Tropical Red Soil under Cabbage Cropping. Int.J.Curr.Microbiol.App.Sci. 10(04): 150-162. doi: https://doi.org/10.20546/ijcmas.2021.1004.014 